\title{
Political Corruption, Trust, and Citizen Evaluations of Democracy: A Cross-National Analysis
}

\author{
EUNJUNG CHOI*
}

\begin{abstract}
Extensive literature on political corruption has addressed how pervasive corruption poses challenges to economic development, distributive justice, and political trust. While there is little doubt about the damaging effects of corruption on economic and political spheres, not much attention is given to the broader consequences of corruption and declining political trust on different facets of democratic governance. This study explores the reciprocal relationships between political corruption and various aspects of the health of democracy, as indicated by political trust and the performance of government as well as by citizens' beliefs in democratic values, norms, and practices. This study finds that political corruption and political trust influence each other and that they, in turn, affect citizens' opinion of democracy. The study also implies that political corruption brings detrimental effects to the deepening and consolidation of democracy in developing nations.
\end{abstract}

Keywords: Political Corruption, Democratic Governance, Political Trust, Cross-National

\footnotetext{
*Assistant Professor, University of South Florida, Florida, USA;

E-mail: echoi@usf.edu;

DOI: 10.16934/isr.15.2.201412.1
} 
The importance of social and political trust in democratic governance has attracted much scholarly attention in the past several decades, and the extensive literature on trust is evident across different fields of social science. One of the first comprehensive studies on this topic is the Trilateral Commission's 1975 work entitled The Crisis of Democracy, which investigated the health of democracy in the United States, Europe, and Japan. The work focused on the problems faced by these oldest democracies, such as declining levels of social trust, citizens' confidence in their political leaders and political systems, and citizens' beliefs about democracies (Crozier, Huntington, and Watanukim 1975). Approximately three decades after the Trilateral Commission's work first appeared, another group of scholars embarked on a successive work, entitled Disaffected Democracies, which explored the same problems in the same democracies. This collaborative work confirmed the Trilateral Commission's findings and concluded that "public confidence in the performance of representative institutions in Western Europe, North America, and Japan has declined since the original Trilateral Commission was issued, and in that sense most democracies are troubled" (Putnam, Pharr, and Dalton 2000). Both studies concurred that the lack of trust or confidence in the government is at the heart of the crisis in democratic societies.

Amid discussions on trust and democracy, political corruption has been blamed for hurting political trust and the performance of government; as a result, citizens' confidence has eroded in their political leaders, entire political systems, and even democratic norms and values. Leading to government inefficiency, theft and tax evasion, slow economic growth, widening inequality, and political instability, political corruption is expected to impair political trust (Uslaner 2005). In terms of the relationship between trust and political corruption, much of the literature suggests that they are connected to form either a virtuous cycle of low corruption-high trust or to a vicious cycle of high corruption-low trust (Uslaner $2005,2008,2012$ ), while some argue the causal direction goes only from trust to corruption (Graeff and Svendsen 2012). Yet despite the little doubt about the damaging effects of corruption on political trust, not much attention has been given to the broader consequences of corruption and the declining political trust on different facets of democratic governance across countries.

This study explores the reciprocal relationships between political corruption and various aspects of the health of democracy as indicated by political trust and the performance of government as well as citizens' beliefs in democratic values, satisfaction with the democratic process, and political participation across countries. This study finds that political corruption and political trust influence one another and that they, in turn, affect citizens' opinion of democratic values and process. Moreover, this article suggests that corruption is more detrimental to nascent democracies in that citizens' satisfaction with the democratic process and the importance of democratic values easily diminish when they have a high level of corruption perception. 


\section{SOCIAL AND POLITICAL TRUST}

In recent decades, most countries-even economically advanced and mature democracies-have struggled with multiple challenges to democratic governance, such as declining political participation, weakening political parties, inefficient management of public resources, and the perception gap between citizens' expectations of government and its actual performance (Della Porta and Vannucci 1999, 4). As both The Crisis of Democracy and Disaffected Democracies acutely warn, citizens' loss of confidence in political elites and institutions-including the legislative, executive, and judicial branches, parties, police, and the military-might be an important indicator of crisis in governance in mature democracies (see also Inglehart 1997; Dalton 2004, 2005; Putnam 200; Catterberg and Moreno 2006). The erosion of citizens' confidence in democratic institutions, procedures, and values is far more serious than their withdrawal of support for their political leaders. Indeed, political leaders come and go; they are reelected or punished in elections depending on their record of performance. After elections, citizens' support for the newly elected leaders is expected to be rejuvenated, which is truly a sign of a healthy democracy. However, citizens' disaffection with political institutions and democratic processes is a deeper problem that often cannot be inexorable and poses menacing challenges to democratic governance.

Scholarly works on trust emphasize the importance of social and political trust as the foundation of a healthy democracy as well as a government's political and economic performance (Uslaner 2008; Bjornskov 2009; Richey 2010). Conceptually speaking, social trust and political trust denote different features of trust. Social trust refers to generalized interpersonal trust that creates a shared identity and sense of communal attachment in society whereas political trust has a somewhat narrower meaning to indicate citizens' confidence in or evaluative orientations toward their representatives and political institutions (Stokes 1962; Hetherington 1998). As Hardin $(2000,34)$ demonstrated, most of the time we do not trust government in the way that we trust other individuals because we do not know government officials and institutions as well as we know people close to us. Therefore, confidence-rather than trust-in the government might be a better way to define citizens' reliability of government. Furthermore, scholars diverge on the sources of the presence or absence of social and political trust; some suggest that trust or the lack thereof originates from differences in social-psychological characteristics (i.e., different personality types with tendencies to trust or distrust other individuals as well as political elites and political systems) (Uslaner 1999, 2000). This approach assumes that the derivation of both interpersonal trust and confidence in the government is the same. Meanwhile, others focus on broader social and cultural inheritances from which specific forms of trust emerge-that is, trust as "the product of social experiences and socialization, especially those found in the 
sorts of voluntary associations of modernity that bring different social types together to achieve a common goal" (Newton and Norris 2000,60). This social and cultural view indicates that social efficacy and political efficacy reinforce one another, resulting in the expectation of a high correlation between the two (Putnam 1993; Inglehart 1997). The final model focuses on the source of confidence in government-that is, government performance; good government performance leads to a higher level of trust whereas poor performance results in a lower level of trust (Coleman 1990; Hetherington 1998; Hardin 2006; Hudson 2006). Unlike the previous two approaches, this model explains the dynamics and different degrees of social and political trust within a society. Whatever the origins, all tend to assume that social and political trust are closely related.

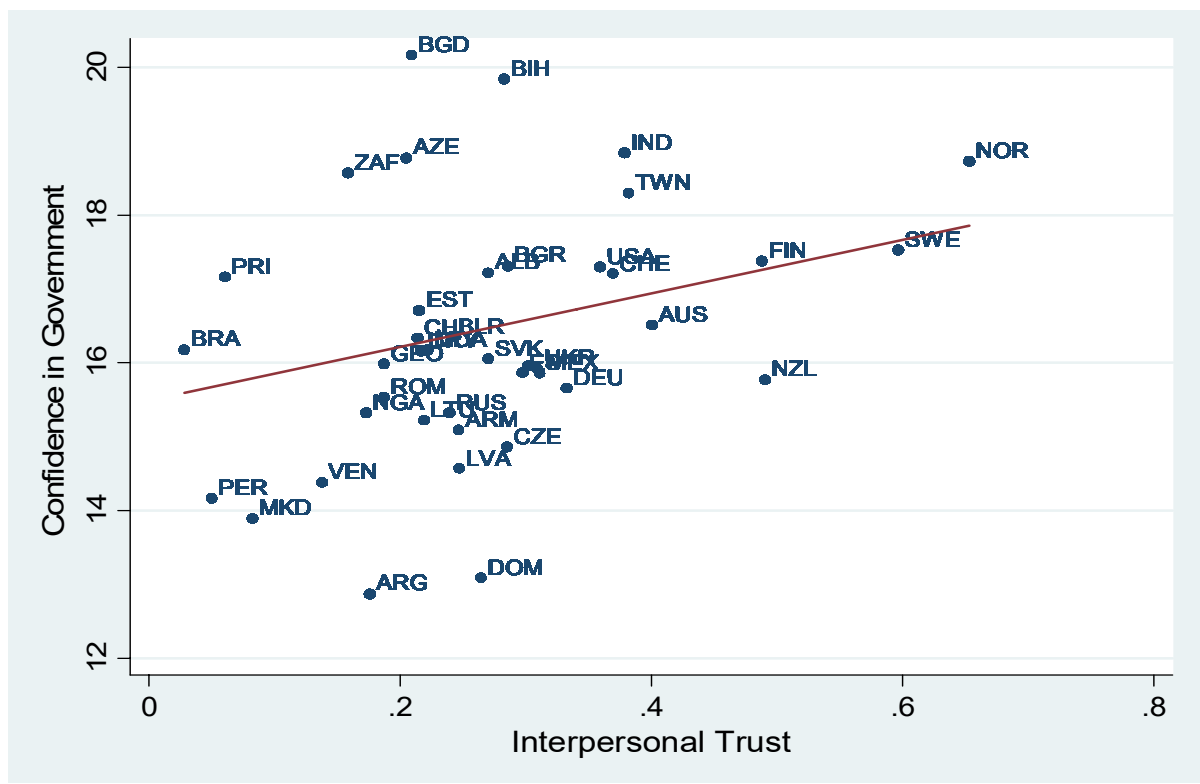

DATA SOURCES: The World Values Survey (WVS) Third Wave (1994-1999).

NOTE: 1 . The full names of the countries are provided in the empirical section. 2 . The original question on confidence or trust in the government in the WVS is: "I am going to name a number of organizations. For each one, could you tell me how much confidence you have in them: [I]s it a great deal of confidence, quite a lot of confidence, not very much confidence or none at all?" The list of organizations includes the armed forces, police, government, political parties, parliament, civil services, and justice system. The confidence variable is an average of all the confidence levels in those organizations in 41 countries. The higher the score is, the higher the confidence is. 3. The questionnaire for interpersonal trust from the WVS is "Generally speaking, would you say that most people can be trusted or that you need to be very careful in dealing with people?" It is coded as 1 for people who say that most people can be trusted and 0 otherwise. The answers are aggregated by country. The interpersonal trust variable here indicates the proportion of people in the 41 countries who trust most people.

\section{Figure 1. Social AND Political TRUST}


Figure 1 exemplifies the relationship between interpersonal trust and political trust (or citizens' confidence in government). Interpersonal trust is positively related to citizens' confidence in the government, but the association is relatively weak ( $r$ $=.277$ ), which might imply that interpersonal trust is not automatically translated into political trust and that both have different origins. Furthermore, the modest correlation between the two is not surprising when we consider the principle of "distrust of authorities" in a well-performing representative democracy, which is the proposition that "those with power cannot or ought not to be trusted" (Warren 1999, 310; see also Norris 1999; Hardin 2006; Marien and Hooghe 2011). That is, healthy democracy is based on the suspicion of, and therefore multiple mechanisms to check, political power. Therefore, showing confidence in government institutions could mean a very different thing from trusting individuals, although it is possible that trustful people are more likely to trust the government.

\section{CORRUPTION, TRUST, AND DEMOCRACY}

Extensive literature on political corruption, commonly defined as "misuse of public office for private gain," presents convincing theoretical and empirical evidence on how corruption accounts for many aspects of poor governance. First, political corruption harms political trust because it weakens the norm of fairness and the rule of law. In a society with a high level of corruption, "the notion of equality and fairness of citizens before institutions is relentlessly compromised by corruption, since governmental services are available only for those who have paid, and policies are made upon the interests of the political elites and their cronies" (Chang and Chu 2006, 260). By discriminating people who pay bribes from those who do not, corruption diverts government resources from public purposes to the private goals that pay bribes, thereby ultimately perpetuating the poverty and inequality gap (Bayley 1966). The wealthy and powerful, therefore, have every incentive to bypass fair political and legal processes to keep their privileges (You and Khagram 2005). By the same token, the have-nots, who lack the instruments of corruption for material gains, do not trust society's political and legal process to be fair and believe that corrupt transactions are something superior to or more effective than legal procedures. The World Values Survey data (1994-1999) attest that citizens in a relatively more corrupt society are more lenient toward unlawful or unethical behavior, such as tax evasion and bribe-taking. ${ }^{1}$ In other words, corruption is perceived as a conventional way of doing business in corruptionpervasive countries.

The ways in which corruption impairs political and economic fairness also result in mismanagement and misallocation of public resources and slower economic growth. Political corruption hinders a country's economic development because it steals tax revenues meant for public expenses, distorts market competition by 
giving preferential benefits to bribe-paying firms and blocking foreign firms from accessing the domestic market, and leads to wider income inequalities by forcing the poor to suffer. When citizens perceive the role of the government in such a way, they tend to naturally look for ways to bypass government rules and regulations. As Della Porta $(2000,205)$ noted, "lack of confidence in government actually favors corruption insofar as it transforms citizens into clients and bribers who look for private protection to gain access to decision-makers." Ultimately, political corruption damages effective government policy-making and implementation and, thus, confidence in the government.

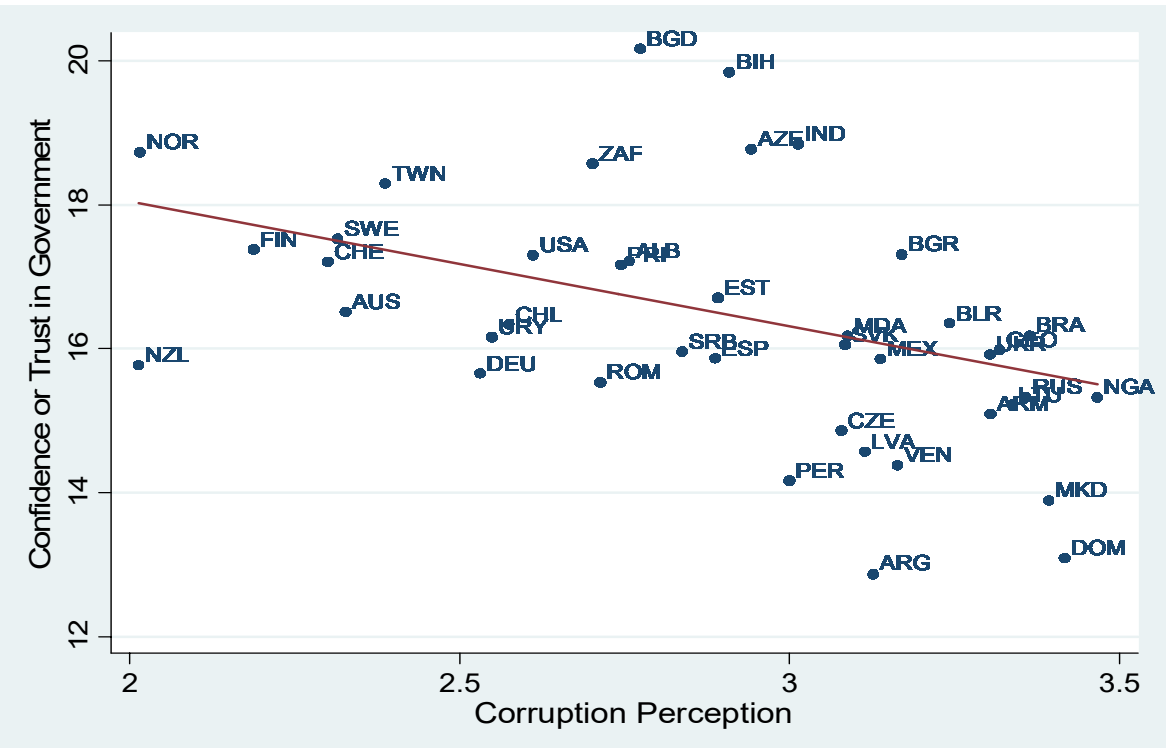

DATA SOURCES: The World Values Survey (WVS) Third Wave (1994-1999).

NOTE: 1. The original question for corruption perception in the WVS is: "How widespread do you think bribe taking and corruption [are] in this country?" It is measured on a 4-point scale.

2 .The measurement for confidence in government is as described in the previous figure.

Figure 2. CORRUPTION PERCEPTION AND CONFIDENCE IN GOVERNMENT

As Figure 2 illustrates, political corruption influences both government policies and the ways in which citizens evaluate their government institutions: Greater political corruption perception is associated with lower citizen confidence in the government. The withdrawal of citizen support for corrupt political elites eventually extends to formal political institutions in general. Still, a more fundamental problem-and truly a crisis-of democracy is the consequence of corruption on citizens' beliefs in democratic norms and values. If citizens identify democracy with inefficiency, unfairness, and corruption, they are more likely to downgrade the value of democracy and might be willing to accept alternative forms of government- 
even those inherently non-democratic. As Figure 3 demonstrates, citizens' preferences for democratic systems significantly drop in countries with high levels of corruption perception.

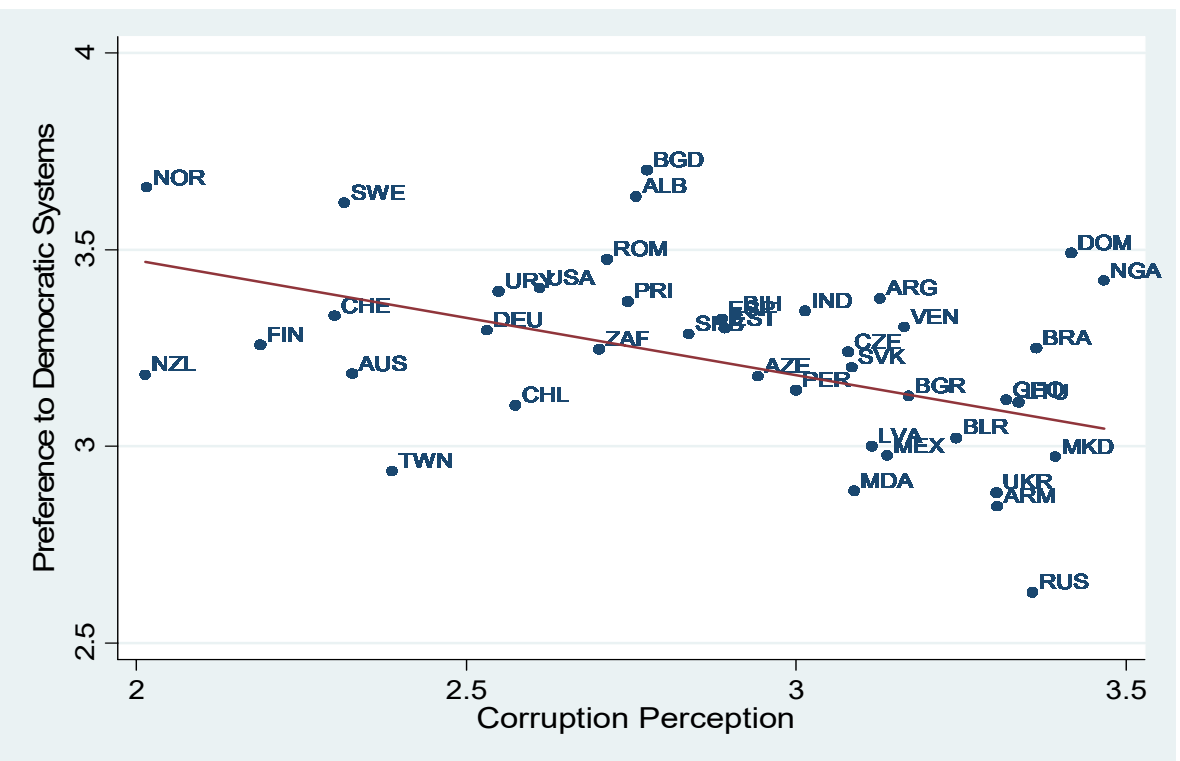

DATA SOURCES: The World Values Survey (WVS) Third Wave (1994-1999).

NOTE: The original question on preference for democratic systems is: "I'm going to read off some things that people sometimes say about a democratic political system. Could you please tell me if you agree strongly, agree, disagree or disagree strongly after I read each one of them? Democracy may have problems but it's better than any other form of government."

Figure 3. Corruption Perception and PREFERENCE FOR DEMOCRATIC SySTEMS

Finally, we present simple correlations among corruption perception, interpersonal trust, citizens' confidence or trust in the government, and citizens' beliefs in democratic values. For the bivariate correlation analysis, additional survey data from the Comparative Study of Electoral Systems (CSES) are included to highlight the relationships between corruption perception and various aspects of democracy. Table 1 confirms that corruption perception is negatively associated with interpersonal and political trust and support for democratic values. Mean-while, social and political trust and citizens' beliefs in democratic values tend to reinforce each other. In addition, a higher corruption perception is related to a lower evaluation of incumbent performance as well as to lower political participation and greater dissatisfaction with how democracy works. Thus far, no conflicting outcome has emerged between the corelational analyses in this study and previous works regarding the influence of corruption on democratic governance. In taking into account the simultaneity among corruption, trust, and different facets of gover- 
nance, the next sections seek to disentangle the complex causal relations among them.

TABLE 1. BIVARIATE CORRELATIONS

\begin{tabular}{l|c|c|c}
\hline & Social Trust & Political Trust & Democratic Values \\
\hline Corruption Perception (WVS) & $-.611^{* * *}$ & $-.423^{* * *}$ & $-.643^{* * *}$ \\
Social Trust & & $.277^{* * *}$ & $.321^{* * *}$ \\
Political Trust & & & $.338^{* * *}$ \\
\hline & Incumbent & Political & Satisfaction with \\
& Performance & Participation & Democratic Process \\
\hline Corruption Perception (CSES) & $-.310^{* * *}$ & $-.127^{* * *}$ & $-.698^{* * *}$ \\
\hline
\end{tabular}

DATA SOURCE: The World Values Survey (WVS) third Wave (1994-1999) and the Comparative Study of Electoral Systems (CSES) Module 2 (2001-2006).

NOTE: The measurements of all the variables are explained in the empirical analysis section.

\section{EMPIRICAL EVIDENCE}

\section{Data and Cases}

In order to test the relationship among corruption, political trust, and citizens' evaluation of democratic governance, the World Values Survey (WVS) and the Comparative Study of Electoral Systems (CSES) are used. For the purpose of this study, the third wave (1994-1999) of the WVS and module 2 (2001-2006) of the CSES are used as they provide relevant variables such as corruption, political trust, and democratic values. ${ }^{2}$ The WVS and CSES datasets include surveys from 56 and 41 countries, respectively. However, only 41 countries from the WVS and 31 countries from the CSES are used for the current research as the survey questionnaires for some countries do not include at least one variable necessary for the full models analyzed here. The sample sizes are relatively small for quantitative analysis, which might produce large confidence intervals and thus result in less precise estimates. However, the two different datasets, the WVS and the CSES, used in this article provide similar results, which coincide with those in much previous literature on political corruption and trust.

\section{(1) The World Values Survey: The Third Wave from 1994-1999}

The cases included from the WVS are as follows: Albania (ALB), Argentina (ARG), Armenia (ARM), Australia (AUS), Azerbaijan (AZE), Bangladesh (BGD), Belarus (BLR), Bosnia and Herzegovina (BIH), Brazil (BRA), Bulgaria (BGR), Czech Republic (CZE), Chile (CHL), Dominican Republic (DOM), Estonia (EST), Finland (FIN), Georgia (GEO), Germany West (DEU), India (IND), Latvia (LVA), 
Lithuania (LTU), Macedonia (MKD), Mexico (MEX), Republic of Moldova (MDA), New Zealand (NZL), Nigeria (NGA), Norway (NOR), Peru (PER), Puerto Rico (PRI), Romania (ROM), Russian Federation (RUS), Serbia (SRB), Slovakia (SVK), South Africa (ZAF), Spain (ESP), Sweden (SWE), Switzerland (CHE), Taiwan (TWN), Ukraine (UKR), the United States (USA), Uruguay (URY), and Venezuela (VEN). The third wave of the WVS includes no Middle Eastern countries. The mean score of the CPI index of the included countries is 5.49, ranging from 0.60 (the least corrupt) to 9.31 (the most corrupt). The average individual corruption perception of each country is highly correlated with the country's CPI score ( $r$ $=.845)$, indicating that corruption perceptions are similar between country experts and business leaders and ordinary citizens. The GDP per capita of the cases ranged from $\$ 293.00$ to $\$ 33,694.00$ at the time of the survey. According to the Freedom House Index, ${ }^{3}$ of the 41 countries, 24 countries are free, 14 are partly free, and 3 are not free.

\section{(2) The Comparative Study of Electoral Systems: Module 2 from 2001-2006}

The cases included from the CSES are as follows: Albania, Australia, Belgium, Brazil, Bulgaria, Canada, Chile, Czech Republic, Finland, France, Germany, Great Britain, Hong Kong, Hungary, Ireland, Italy, Japan, South Korea, Mexico, Netherlands, New Zealand, the Philippines, Poland, Portugal, Romania, Russia, Slovenia, Spain, Switzerland, Taiwan, and the United States. The cases do not include Middle Eastern or African countries. Module 2 of the CSES does include one Middle Eastern country, Israel, but the empirical analysis of this study excludes that case. The average score of the CPI index among the cases is 3.927 , ranging from 0.300 to 7.6. The correlation between the mean individual corruption perception of each country and the CPI score of each is .863. The high correlations among various corruption indicators weaken the suspicion of bias in the CPI index. The GDP per capita ranged from $\$ 1,073.00$ to $\$ 38,236.00$ at that time of the survey. Of the 31 countries, 2 are either not free (Russia) or partly free (Albania); the remaining countries are considered to be free.

\section{Methods}

In order to examine the effects of corruption on political trust, government performance, and democratic governance, this study applies simultaneous equation models (SEM) as corruption, political trust, and government performance are not only exogenous but also endogenous. These variables influence one another and affect other endogenous variables, such as citizens' evaluation of the democratic process and the weight of democratic values. The diagram below illustrates the relationships. As indicated in the diagram, corruption perception is expected to 
have negative relationships with social trust and all the democratic governance measures.

Diagram. Social and Political Trust, Corruption, AND Governance: A CAUSAL CONNECTION

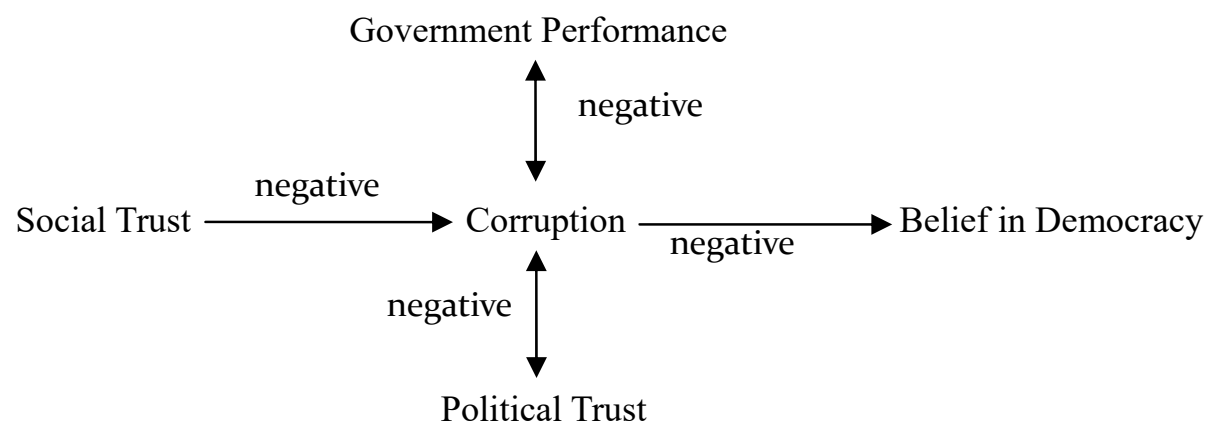

To test the relationships among these interrelated variables, five simultaneous equation models are created, each for two or three multiple-equations models: (1) political trust and corruption perception; (2) political trust, corruption perception, and the importance of democratic values; (3) government performance and corruption perception; (4) government performance, corruption perception, and satisfaction with the democratic process; and (5) government performance, corruption perception, and political participation. Three-stage least squares (3SLS) regression was utilized to estimate all the SEM models. Estimates of the first- and secondstage instrumented values for the endogenous variables replaced the endogenous ones in the final-stage of the multiple equations. The WVS provides the data for the equations for (1) and (2) while the CSES renders the data for the remaining SEM models. ${ }^{4}$ All variables included in each model are aggregated by country. The details on the variables and their measurements are discussed with the empirical results of each model.

\section{Empirical Analysis}

\section{(1) Corruption and Political Trust}

The pervasive perception of corruption in a society is supposed to decrease political trust; distrust in the government in turn increases corruption perception. Therefore, this section analyzes the simultaneous relationship between corruption and political trust. Measuring corruption perception, the WVS asks about the extent of corruption among public officials on a 4-point scale: 1 for "almost no 
public officials engaged in it;" 2 for "a few are;" 3 for "most are;" and 4 for "almost all public officials are engaged in it." Political trust is often measured by the following questions: How often can you trust the government to do what is right? Would you say that this country is run by a few big interests looking for themselves or that it is run for the benefit of all the people? This approach is detailed in Hetherington and Rudolph (2008) and in Morris and Klesner (2010). However, considering that political trust is defined as citizens' trust or confidence in their representatives and political institutions (Chang and Chu 2006; Morris and Klesner 2010), this empirical analysis uses more inclusive but specific measurements. The WVS asks how much confidence respondents have in various government institutions, such as the armed forces, police, legislature, civil services, political parties, the justice system, and the government, using a 4-point scale: a great deal of confidence; quite a lot of confidence; not very much confidence; or none at all. To create an index for trust or confidence in the government, all the answers are reverse coded so that a higher number reflects a higher level of trust. All scores were then averaged by country. Table 2 summarizes the level of trust in various political institutions in 41 countries. The level of trust in each institution, which ranges from 1 to 4 , is not high across the board. The armed forces receive the highest trust from citizens while people have the lowest confidence in political parties. The difference means test ( $t$-test) denotes that the difference in trust between the two institutions is statistically significant.

TABle 2. TRUST In Political Institutions In 41 CoUnTRIES

\begin{tabular}{llc}
\hline \multicolumn{1}{c}{ Institutions } & Mean & Standard Deviation \\
\hline National Government & 2.343 & .336 \\
\hline Legislature & 2.236 & .328 \\
\hline Justice System & 2.431 & .248 \\
\hline Armed Forces & 2.674 & .297 \\
\hline Police & 2.407 & .352 \\
\hline Civil Services & 2.372 & .260 \\
\hline Political Parties & 2.009 & .271 \\
\hline
\end{tabular}

DATA SOURCE: The WVS third wave.

The equation for corruption perception includes the following independent variables: the levels of political and social (or interpersonal) trust, the extent of tolerance of corrupt behaviors, Protestant population, and education levels as well as regional dummy variables. To explain variations in the level of political trust across countries, we included the variables of corruption perception, social trust, tolerance of corrupt behaviors, religious population, education levels, and regional dummy variables. The measurement of social or interpersonal trust is quite strai- 
ghtforward in the WVS, and it is based on the question of whether or not most people can be trusted. Given that political trust is a particular type of trust confined to political objects (Lane 1959; Brehm and Rahn 1997; Morris and Klesner 2010), interpersonal trust as a general form of trust is expected to influence political trust as well as corruption perception. Another independent variable predicting both corruption perception and political trust is "tolerance," which indicates the tolerance individuals have for corrupt behaviors. The WVS asks how justifiable it is to claim government benefits to which a person is not entitled, to cheat on taxes, and to accept bribes. People who consider these behaviors to be acceptable should be less likely to perceive political corruption and more likely to trust the government as they tend to be the beneficiaries of corruption. As an instrument for the corruption equation, the percentage of Protestants is included as the existing literature suggests that Protestant-dominant countries are less corrupt, although the association is not robust. The political trust equation includes the population belonging to a religious denomination (the variable named "Belief") as an instrument variable. According to the social capital literature, a sense of belonging to groups or participation in voluntary associations such as faith-based organizations is expected to increase political trust (Putnam 1994, 2000; Smidt 2003; Alexander 2007). The following three-stage least squares estimations include a system of simultaneous equations of political corruption and political trust.

$$
\begin{aligned}
& \text { Corruption }=\underset{(.047)}{3.301^{* * *}-\left(.039^{* * * *}\right.} \text { Pol_Trust }-\underset{(.012)}{.129^{* * *}} \text { Soc_Trust }+\underset{\left(.029^{*}\right)}{.001 *} \text { Tolerance }
\end{aligned}
$$

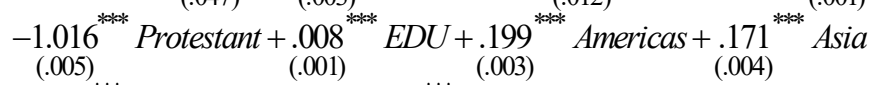

$$
\begin{aligned}
& +\underset{(.003)}{.283^{* * *} \text { Eastern_Europe }+.655^{* * *} \text { Africa }} \\
& \left(R^{2}=.785 \quad \text { Nof Countries }=41\right) \\
& { }^{*} \mathrm{p} \leq .1,{ }^{* *} \mathrm{p} \leq .05,{ }^{* * *} \mathrm{p} \leq .01 \\
& \text { Pol_Trust }=\underset{(.119)}{16.276^{* * *}-\underset{(.035)}{171} \text { Corruption }}{ }^{* * *}+\underset{(.078)}{2.826^{* * *}} \text { Soc_Trust }-\underset{(004)}{176^{* * *}} \text { Tolerance } \\
& +\underset{(.037)}{1.873^{* * *}} \text { Belief }-\underset{(.009)}{.197^{* * * *}} \text { EDU }-\underset{(.024)}{.419^{* * *}} \text { Americas }+\underset{(.023)}{.648^{* * *}} \text { Asia } \\
& +.609^{* * * *} \text { Eastern_Europe }+\underset{(.030)}{.937^{* * * *}} \text { Africa } \\
& \left(R^{2}=.308 \quad \text { N of Countries }=41\right) \\
& { }^{*} \mathrm{p} \leq .1,{ }^{* *} \mathrm{p} \leq .05,{ }^{* * *} \mathrm{p} \leq .01
\end{aligned}
$$

As expected, Eq. (1) and Eq. (2) indicate that a larger population with a higher confidence in government institutions leads to a lower corruption perception; political institutions in a country with a higher corruption perception are considered 
less trustworthy. In other words, when the two equations are considered together, a higher political trust lowers corruption perception and a higher corruption perception hurts trust in government institutions. Social trust brings expected outcomes; a higher interpersonal trust lowers corruption perception and increases trust in political institutions. Another interesting variable is "tolerance," representing tolerance toward corrupt behaviors. Unexpectedly, countries with more people justifying corrupt behaviors tend to have higher corruption perception and lower political trust, suggesting that people realize that a certain behavior is corrupt, but accept it and engage in it because it is commonplace. This is fortunate, on the one hand, in that people distinguish ethical behaviors from unethical ones; however, on the other hand, it is problematic in that they do not want to be excluded from taking advantage of the benefits accruing from corruption. The religion-related variables bring consistent outcomes with previous studies: Protestant-dominant countries tend to have a lower corruption perception. A country with a larger population belonging to religious denominations has a higher level of political trust.

The level of education significantly influences the corruption perception and political trust as well. Countries with more educated people tend to have higher corruption perception and lower political trust. Highly educated individuals might be more aware of the existence of political corruption and, thus, trust their government less. Finally, regional differences exist in corruption perception and political trust. Compared to Western European countries, countries in the rest of the world have a higher corruption perception, which is consistent with the results from other experts' survey-based corruption indicators, such as the CPI. On the other hand, except for countries in the Americas, Western European states have the lowest trust in the government. This seems contradictory in that people in countries with a higher corruption perception tend to trust their government institutions more.

\section{(2) Corruption, Political Trust, and Democratic Values}

Another important consequence of high corruption perception and low political trust is their corrosive effect on how people think about democratic norms and values. Democratic norms and values include multiple aspects; thus, the WVS asks diverse questions to measure how people think about democratic culture and institutions. Here, eight questions from the WVS are used to measure democratic values. These questions are divided into three categories: (1) What do people think about different types of political systems ("having a strong leader," "having experts make decisions," "having the army rule," and "having a democratic system") as a way of governing their country? (2) How effective is a democratic political system in running the economy, making decisions, and maintaining order? and (3) Is democracy a better form of government than others although it has problems? All answers are indicated on a 4-point scale. Similar to the index of trust or confidence 
in the government, the answers to these questions are averaged by country. The higher the average score, the more valuable democracy is to people in that country. The democratic value equation includes corruption perception, political trust, population with religion, and level of education as well as regional dummies. The equation also includes the level of income as an instrumental variable as economic development and democracy are known to be highly correlated (Lipset 1959; Przeworski et al. 1996). The following 3SLS estimation addresses the democratic values equation. The equations of corruption and political trust are not presented here as the focal point in this section is how corruption and political trust influence the importance of democratic values. However, the two equations are the same as Eq. (1) and Eq. (2) and their outcomes are very similar to them.

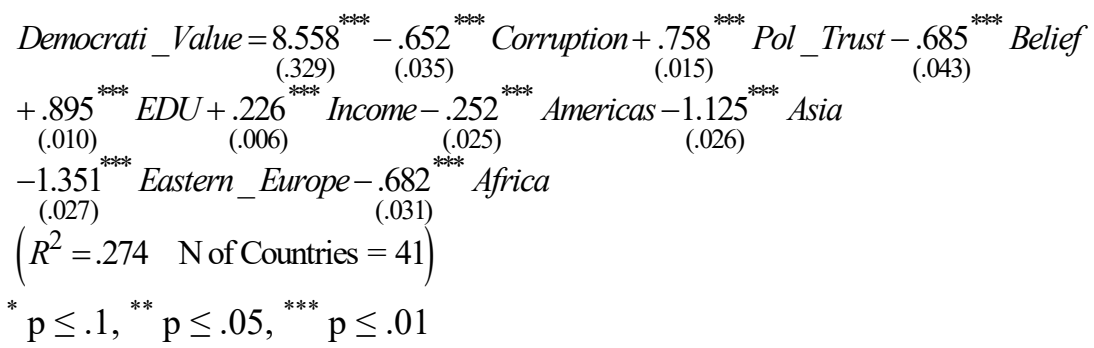

The results demonstrate that the higher corruption perception hurts citizens' support for democratic systems and values. The negative effect of high corruption perception on democratic values does not change even after performing separate tests for each category of the democratic values questions. The higher political trust boosts support for democratic values, as expected. However, the larger the population belonging to religious denominations becomes, the lower the support for democratic values becomes. It is quite puzzling that a larger religious population leads to a higher political confidence or trust and yet lowers support for democratic norms and values. Meanwhile, countries with higher education and incomes tend to support democratic values more than countries with lower levels of education and income. Finally, concerning regional diversity, Western European nations have a higher support for democratic values than the rest of the regions.

\section{(3) Corruption and Government Performance}

This section uses the CSES data to address how the corruption and evaluation of an incumbent's performance influence each other and affect the evaluation of democratic processes and participation in politics. The first step is to examine the simultaneous relationship between corruption perception and the incumbent's performance. The CSES asks respondents to evaluate their government's or president's performance over the past years on a 4-point scale, ranging from "a very 
good job" to "a very bad job." To estimate government performance, variables such as corruption perception, unemployment, education, and regional dummies are included. The CSES uses survey questions about corruption perception similar to the WVS: How widespread do you think corruption such as bribe-taking is amongst politicians? This is also measured on a 4-point scale from "very widespread" to "quite widespread," "not very widespread," and "it hardly happens at all." For the sake of consistency, the scales are reversed in the current examination so that a higher number means a better evaluation of incumbent performance and a higher corruption perception. The corruption equation includes incumbent performance, level of education, union or other professional membership, Protestant population, and regional dummies. We adopted Morris and Klesner's model to include union or other professional memberships to represent social capital (Morris and Klesner 2010). This variable is not a part of the previous corruption perception equation as the WVS third wave survey does not address the question of professional association membership.

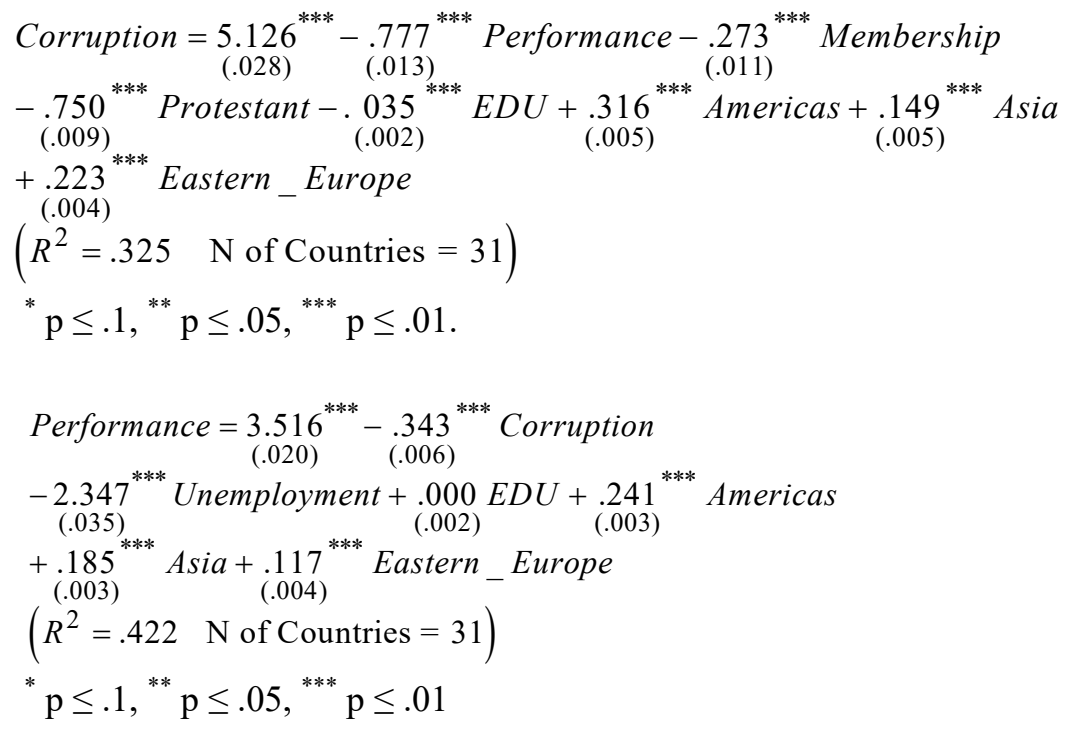

The 3SLS estimation of the corruption equation (Eq. (4)) shows that, the higher the performance rating, the lower the corruption perception. When the government or incumbent performs well, citizens are willing to overlook the issue of corruption. At the same time, a higher corruption perception brings down the performance rating (see Eq. (5)). Countries with a greater number of people who are members of a union or professional associations have a lower corruption perception, which also holds true for the Protestant population. Education level is not a significant factor in predicting government performance ratings, but it significantly lowers corruption perception, thereby implying that a country's edu- 
cational achievement indirectly affects the evaluation of incumbent performance through corruption perception. As in the SEM model of corruption perception (Eq. (1)) and political trust (Eq. (2)), countries in the Americas, Asia, and Eastern Europe have a higher corruption perception, but they also receive a better performance rating than Western European countries. This might be due to the fact that developing countries have much more room for improvement in their economy and other areas of governance than already developed countries, in which citizens have higher standards of government performance. In other words, performance ratings in developing countries can be higher in both subjective and objective terms. Unemployment, an instrument variable of the performance equation (Eq. (5)), has a negative effect on the evaluation of incumbent performance: A higher unemployment rate results in a lower evaluation of government performance, which is consistent with much of the economic voting literature.

\section{(4) Corruption, Performance, and Satisfaction with the Democratic Process}

This section examines the effects of corruption and performance on satisfaction with the democratic process across countries. In countries with a greater corruption perception, people should be less satisfied with how democracy works in their countries; meanwhile, in countries with more people who like what their governments have done, people should be more satisfied. The CSES asks, "On the whole, are you very satisfied, fairly satisfied, not very satisfied, or not at all satisfied with the way democracy works in [country]?" Consistent with the previous analyses, this section also reverses the coding scheme so that the higher the number, the more satisfied a person is with the democratic process. The average score by country is used in this analysis. In the system of simultaneous equations, the corruption perception and government performance equations remain the same, providing similar results as Eq. (4) and Eq. (5). The following 3SLS estimation of the final-stage equation, satisfaction with the democratic process (Eq. (6)), includes population with religion, education, income, and regional dummy variables in addition to corruption perception and performance evaluation.

$$
\begin{aligned}
& \text { Satisfaction }=\underset{(.036)}{1.812^{* * *}}-\underset{(.007)}{.103^{* * *}} \text { Corruption }+\underset{(.012)}{.669^{* * *}} \text { Performance } \\
& +.037^{* * *} \text { Belief }-.330^{* * *} \text { Income }+\underset{(.007)}{.0061^{* * *}} \text { EDU }-\underset{(.004)}{.212^{* * *}} \text { Americas } \\
& -.112^{* * * *} \text { Asia }-.195^{* * *} \text { Eastern_Europe } \\
& \left(R^{2}=.589 \quad \mathrm{~N} \text { of Countries }=31\right) \\
& { }^{*} \mathrm{p} \leq .1,{ }^{* *} \mathrm{p} \leq .05,{ }^{* * *} \mathrm{p} \leq .01
\end{aligned}
$$

As expected, a higher corruption perception leads to lower satisfaction with 
the way in which democracy works in a country, while good incumbent performance results in higher satisfaction. The larger the religious population becomes in a country, the higher the satisfaction with the democratic process. This contrasts with the democratic values equation (Eq. (3)), in which countries with a larger population identifying with a religious denomination tend to support democratic values less. Another notable difference in outcomes between Eq. (3) and Eq. (6) is the effect of income. Although higher income-earning countries are more likely to support democratic values, they are not very satisfied with how democracy works, suggesting that they remain supportive of democracy even though they think it is not working well. Countries in the Americas, Asia, and Eastern Europe have lower satisfaction with the democratic process than those in Western Europe.

\section{(5) Corruption, Performance, and Political Participation}

This section discusses how corruption perception and government performance influence various types of political participation, such as voting, campaigning, contacting a politician or government official, persuading others, and protesting. Each form of political participation is measured as a dummy variable, coded 1 for participants and 0 for non-participants; the sums are then averaged by country. The 3SLS estimation of political participation follows. In the three equations model, the corruption perception and performance equations remain unchanged from EQ4 and Eq. (5), rendering similar outcomes.

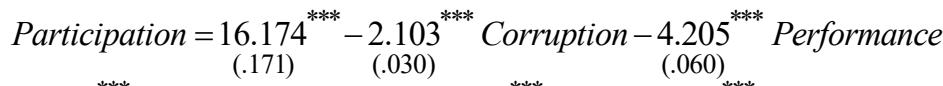

$$
\begin{aligned}
& -.595^{\text {*** }} \text { Belief }+\underset{(.025)}{.022} \text { Income }+.4200^{\text {**** }} E D U+\underset{(.007)}{1.758^{* * *}} \text { Americas } \\
& +1.133^{* * *} \text { Asia }+. .443^{* * *} \text { Eastern_Europe } \\
& \left(R^{2}=.049 \quad \mathrm{~N} \text { of Countries }=31\right) \\
& { }^{*} \mathrm{p} \leq .1,{ }^{* *} \mathrm{p} \leq .05,{ }^{* * *} \mathrm{p} \leq .01
\end{aligned}
$$

The results of the participation equation confirm the negative effect of corruption on political participation. As more people perceive that their politicians are corrupt, fewer people tend to participate in politics. In other words, corruption hinders people not only from voting, but also from participating in politics in alternative ways, such as campaigns and protests. This result confirms the finding from previous studies that voters generally restrain themselves from voting rather than vote against the incumbents due to pervasive corruption and poor governance (McCann and Dominguez 1998; Seligson 2002; Davis, Ai Camp, and Coleman 2004). Furthermore, the more satisfied people are with incumbent's performance, the less they are engaged in politics. This seems to support the negative voting 
argument that people respond more strongly to a negative outcome than to a positive one (Key 1966; Bloom and Price 1975; Kernell 1977; Lau 1983). Put differently, people are more likely to express their views through various forms of political participation when they have complaints. Countries with a larger religious population have a lower participation rate. On the other hand, a larger population with higher education and income levels results in greater political participation, which conforms to the results from the previous political participation literature (Verba and Nie 1972; Wolfinger and Rosenstone 1980; Leighley and Nagler 1992). However, although Western European countries have achieved high education and income levels, they have lower political participation than countries on other continents. Low voter turnout is common among advanced democracies, which might indicate that people in those countries are quite satisfied with the democratic process itself, as previously indicated, or do not expect much change in their society by participating, as political institutions and economic systems are already settled.

\section{CONCLUSIONS}

The end of the Cold War and the triumph of liberal democracy and the free market in the late twentieth century ironically revealed a crisis in democracy in both developed and developing societies. Numerous scholarly works have uncovered that the major cause of the crisis in democracy emanates from political corruption, which in turn diminishes political trust. Previous literature has revolved around two contradictory causal arguments: One group of scholars focuses on how political corruption affects political trust (or citizens' confidence in the government) as well as political and economic performance of a country while another group reverses the logic to suggest that political trust itself is an outcome of better governmental performance. However, the arguments should complement one another as the two components influence and co-constitute each other to create either a virtuous cycle or a vicious cycle between political trust and corruption.

The empirical analysis has centered on the harmful influence of political corruption on political trust, citizens' perception of government performance, and their beliefs about democratic values and processes; and the level of perceived corruption brings detrimental effects to all these aspects. However, several outcomes are particularly worth noting. First, the levels of corruption perception and political trust influence each other. In turn, high levels of corruption perception and the lack of political trust weaken citizens' beliefs about and support for democratic norms and values. Second, the level of perceived corruption and citizens' evaluation of their government's performance shape each other. Specifically, citizens' evaluation of government performance is low when they consider their governments to be corrupt, while decent government performance reduces citizens' perceptions 
of political corruption. As a result, corrupt politicians can often get away with their wrongdoings when they made significant progress in economic conditions. Finally, both political corruption and contentment with government performance depress citizens' general political participation, which indicates that people abstain from politics not only because rampant political corruption decreases political efficacy, but also because there is not much to change.

There is little evidence to reverse the verdict of malignant effects of political corruption on various elements of democratic governance. However, the implications of the outcomes are particularly troublesome for nascent democracies. Established democracies with less corruption tend to have a higher satisfaction with democratic process and support for democratic values, even though they have a lower political trust in various government institutions than the rest of the world. On the other hand, belief in democracy among newly democratized and less developed countries that are more corrupt is more likely to be susceptible to government performance and confidence in government and thus can be wavering. Future studies of political corruption should examine under what circumstances political corruption is more or less destructive as such information would help provide potential solutions to attenuate the consequences.

\section{REFERENCES}

Alexander, Marcus. 2007. Determinants of Social Capital: New Evidence on Religion, Diversity and Structural Change. British Journal of Political Science 37: 368-377.

Bayley, David H. 1966. The Effects of Corruption in a Developing Nation. Western Political Quarterly 19: 719-732.

Bloom, Howard S. and H. Douglas Price. 1975. Voters Response to Short-run Economic Conditions. American Political Science Review 69: 1240-54.

Bjornskov, Christian. 2009. Economic Growth. In Handbook of Social Capital, eds. Gert T. Svendsen and Gunnar L. H. Svendsen. Cheltenham, UK: Edward Elgar.

Brehm, John and Wendy Rahn. 1997. Individual-level Evidence for the Causes and Consequences of Social Capital. American Journal of Political Science 41: 999-1023.

Catterberg, Gabriela and Alejandro Moreno. 2006. The Individual Bases of Political Trust: Trends in new and established democracies. International Journal of Public Opinion Research 18: 31-48.

Chang, Eric and Yun-han Chu. 2006. Corruption and Trust: Exceptionalism in Asian Democracies? Journal of Democracy 68: 260-271.

Coleman, James. 1990. Foundations of social theory. Cambridge, MA: Harvard University Press. 
Crozier, Michael, Samuel P. Huntington, and JojiWatanuki. 1975. The Crisis of Democracy: Report on the Governability of Democracies to the Trilateral Commission. New York: New York University Press.

Dalton, Russell. J. 2004. Democratic challenges, democratic choices: The erosion of political support in advanced industrial democracies. Oxford, United Kingdom: Oxford University Press.

Dalton, Russell. J. 2005. The social transformation of trust in government. International Review of Sociology 15: 133-154.

Davis, Charles L., Roderic Ai Camp, and Kenneth M. Coleman. 2004. The Influence of Party Systems on Citizens' Perceptions of Corruption and Electoral Response in Latin America. Comparative Political Studies 37: 677-703.

Della, Porta, Donatella and Alberto Vannucci. 1999. Corrupt Exchanges: Actors, Resources, and Mechanisms of Political Corruption. New York: Aldine de Gruyter.

Donatella, Della Porta. 2000. Social Capital, Beliefs in Government, and Political Corruption. In Disaffected Democracies: What's Troubling the Trilateral Countries?, eds. Susan Pharr and Robert D. Putnam. Princeton: Princeton University Press.

Graeff, Peter and Tinggaard Svendsen. 2013. Trust and corruption: The influence of positive and negative social capital on the economic development in the European Union. Quality and Quantity 47: 2829-2846.

Hardin, Russell. 2000. The Public Trust. In Disaffected Democracies: What's Troubling the Trilateral Countries?, eds. Susan Pharr and Robert D. Putnam. Princeton: Princeton University Press.

Hardin, Russell. 2006. Trust. Cambridge: Polity Press.

Hetherington, Marc J. 1998. The Political Relevance of Political Trust. American Political Science Review 92: 791-808.

Hetherington, Marc J. and Thomas J. Rudolph. 2008. Priming, Performance, and the Dynamics of Political Trust. Journal of Politics 70: 498-512.

Hudson, John. 2006. Institutional trust and subjective well-being across the EU. Kyklos 59: 43-62.

Inglehart, Ronald. 1997. Modernization and postmodernization: Cultural, economic, and political change in 43 societies, Princeton, NJ: Princeton University Press.

Kernell, Samuel. 1977. Presidential Popularity and Negative Voting. American Political Science Review 71: 44-66.

Key, V. O. 1966. The Responsible Electorate New York: Random House.

Lane, Robert E. 1959. Political Life: Why and How People Get Involved in Politics, New York: Free Press.

Lau, Richard R. 1982. Negativity in Political Perception. Political Behavior 4: 353-378. 
Leighley, Jan E. and Jonathan Nagler. 1992. Individual and Systematic Influences on Turnout: Who Votes? 1984. Journal of Politics 54: 718-740.

Lipset, Seymour Martin. 1959. Some Social Requisites of Democracy: Economic Development and Political Legitimacy. American Political Science Review 53: 69-105.

Marien, Sofie and Marc Hooghe. 2011. Does Political Trust Matter? An Empirical Investigation into the Relation between Political Trust and Support for Law Compliance. European Journal of Political Research 50: 267-291.

McCann, James A. and Jorge I. Dominguez. 1998. Mexicans React to Electoral Fraud and Political Corruption: An Assessment of Public Opinion and Voting Behavior. Electoral Studies 17: 483-504.

Morris, Stephen D. and Joseph L. Klesner. 2010. Corruption and Trust: Theoretical Considerations and Evidence from Mexico. Comparative Political Studies 43: 1258-1285.

Newton, Kenneth and Pippa Norris. 2000. Confidence in Institutions: Faith, Culure, or Performance? In Disaffected Democracies: What's Troubling the Triaeral Countries?, eds. Susan Pharr and Robert D. Putnam. Princeton: Princeon University Press.

Norris, Pippa. 1999. The Growth of Critical Citizens. In Critical Citizens: Global Support for Democratic Government, ed. Pippa Norris. Oxford: Oxford University Press.

Richey, Sean. 2010. The Impact of Corruption on Social Trust. American Politics Research 38: 676-690.

Przeworski, Adam, Michael Alvarez, Jose Antonio Cheibub, and Fernando Limongi. 1996. What Makes Democracy Endure? Journal of Democracy 7: 39-55.

Putnam, Robert D. 1993. Making democracy work: Civic traditions in modern Italy. Princeton, NJ: Princeton University Press.

Putnam, Robert D. 2000. Bowling Alone. New York: Simon and Schuster Paperbacks.

Putnam, Robert D., Robert Leonardi, and Raffaella Y. Nanetti. 1994. Making Democracy Work: Civic Traditions in Modern Italy. Princeton: Princeton University Press.

Putnam, Robert D., Susan J. Pharr, and Russell J. Dalton. 2000. Introduction: What's Troubling the Trilateral Democracies? In Disaffected Democracies: What's Troubling the Trilateral Countries?, eds. Susan Pharr and Robert D. Putnam. Princeton: Princeton University Press.

Seligson, Mitchell A. 2002. Trouble in Paradise? The Erosion of System Support, 1978-1999. Latin American Research Review 37: 160-85.

Smidt, Corwin E., ed. 2007. Religion as Social Capital: Producing the Common Good. Waco: Baylor University Press.

Stokes, Donald E. 1962. Popular Evaluations of Government: An Empirical Asessment. In Ethics and Bigness: Scientific, Academic, Religious, Political, 
and Military, eds. Halan Cleveland and Harold D. Lasswell. New York: Harper and Brothers.

Uslaner, Eric M. 1999. Democracy and Social Capital. In Democracy and Trust, ed. Mark Warren. Cambridge: Cambridge University Press.

Uslaner, Eric M. 2000. Producing and Consuming Trust. Political Science Quarterly 115: 569-90.

Uslaner, Eric M. 2005. Trust and Corruption. In The New Institutional Economics of Corruption. eds. Johann Graff Lambsdorf, Markus Taube, and Matthias Schramm. New York: Routledge.

Uslaner, Eric M. 2008. Corruption, Inequality, and the Rule of Law: The Bulging Pocket Makes the Easy Life. New York: Cambridge University Press.

Uslaner, Eric M. 2013. Trust and corruption revisited: how and why trust and corruption shape each other. Quality and Quantity 47: 3603-3608.

Verba, Sidney and Norman Nie. 1972. Participation in America: Political democracy and social equality. New York: Harper and Row.

Warren, Mark. 1999. Democratic Theory and Trust. In Democracy and Trust, eds. Mark Warren. Cambridge: Cambridge University Press.

Wolfinger, Raymond E. and Steven J. Rosenstone. 1980. Who Votes? New Haven: Yale University Press.

You, Jong-Sung and Sanjeev Khagram. 2005. A Comparative Study of Inequality and Corruption. American Sociological Review 70: 136-157. 


\section{ENDNOTES}

1 The World Values Survey (1994-1999) asks questions about how justifiable each of the following statements are: (1) claiming government benefits to which you are not entitled, (2) cheating on taxes, and (3) someone accepting a bribe. Each is coded on a 10-point scale, ranging from 1 (never justifiable) to 10 (always justifiable). The tolerance variable is constructed by combining these three questions. The correlation coefficient between tolerance to corruption and the level of corruption perception is 493 .

2 After the third wave, the WVS does not include the overall corruption perception variable.

3 See the official website of Freedom House (http://www.freedomhouse.org) for more details on how the organization surveys and rates countries' political freedom.

4 The WVS third wave does not include a government performance question, while the CSES (module 2) does not ask a question about social and political trust. 